\title{
Herbal prevention and treatment of nipple trauma and/or pain in Iranian studies: a systematic review
}

\author{
Nayereh As'adi ${ }^{1}$, Nourossadat Kariman ${ }^{2 *}$ \\ ${ }^{1}$ Student Research Committee, School of Nursing and Midwifery, Shahid Beheshti University of Medical Sciences, Tehran, Iran \\ ${ }^{2}$ Midwifery and Reproductive Health Research Center, Department of Midwifery and Reproductive Health, School of Nursing and Midwifery, Shahid \\ Beheshti University of Medical Sciences, Tehran, Iran
}

\section{A R T I C L E IN F O}

Article Type:

Review

\section{Article History:}

Received: 3 January 2018

Accepted: 2 June 2018

\section{Keywords:}

Herbal remedies

Medicinal plants

Nipples

Fissure

Pain

Iran

\begin{abstract}
A B S T R A C T
Introduction: Adequate nutrition during infancy is essential for lifelong health and wellbeing. However, painful nipple trauma is problematic for mothers and may lower the prevalence of breastfeeding. This systematic review was conducted to assess herbal prevention and treatment of nipple trauma and/or pain in Iranian studies.

Methods: All the Iranian indexed publications in English and in Persian were searched with the key words of "nipple trauma" and "nipple pain" from inception to 26 December 2017 on indexing sites of PubMed, Proquest, Scopus, Science Direct, Medline, SID, IranMedex, Magiran, and Google Scholar. The results were reported qualitatively. Eleven randomized clinical trials (RCTs) with total sample size of 1218 were included in this systematic review. Different herbal remedies were used in included articles. The articles were investigated through Jadad scale. Studies that scored 3 or more on Jadad scale were selected. The results were reported qualitatively. Only RCTs were considered.

Results: Pistacia atlantica (Saqez), Ziziphus jujuba, curcumin, menthol, Aloe vera, Calendit - E (Calendula officinalis and Echinacea angustifolia) were the most effective treatments of nipple trauma and/or pain. In one study, peppermint water was more effective than breast milk in preventing nipple cracks and in another study nipple crack was less in women using peppermint compared with those who used lanolin ointment or placebo.

Conclusion: As each study used a special medicinal plant in this review, judgement about the definitive efficacy of these remedies needs further precise studies.
\end{abstract}

Implication for health policy/practice/research/medical education:

The results of this review revealed that some medicinal plants can be considered as beneficial remedies for both prevention and treatment of nipple trauma and/or pain. These remedies do not impose any harmful side effects on the mother or baby and can cure the nipple injuries properly. So they can be offered by health care providers and experts to be used safely by the mothers. Please cite this paper as: As'adi N, Kariman N. Herbal prevention and treatment of nipple trauma and/or pain in Iranian studies: a systematic review. J Herbmed Pharmacol. 2018;7(3):168-175. doi: 10.15171/jhp.2018.27.

\section{Introduction}

Adequate nutrition during infancy is essential for lifelong health and wellbeing. Infants should be exclusively breastfed for the first 6 months of life to achieve optimal growth, development and health (1). However, painful nipple trauma is problematic for mothers and may cause severe pain and mastitis leading low prevalence of breastfeeding $(2,3)$. It also can cause physiological distress and problems in general activity, sleep, mood and mother/ baby relationship (4). Nipple traumas are characterized by the presence of pain sensation in suction lesions of nipple which includes edema, erythema, fissures, cracks, blisters, abrasions and ecchymosis associated with breast feeding (5-7). It is located around the base of the nipple and frequently found at the top part of the nipple which involves dermis and epidermis (8). Nipple trauma confronts breastfeeding women 3-6 days postpartum and in some mothers may persist to 6 weeks after delivery $(9,10)$. Previous reports have considered the creation of a proper feeding position by the mother and baby and correct attachment of the baby to the breast as important factors in successful breastfeeding (11). There are various 
medicinal, non-medicinal and herbal remedies for the prevention and treatment of nipple pain and trauma (12). But conclusive judgement about the efficacy of these interventions, requires further and more accurate studies with adequate sample sizes (13). Some studies have been done regarding the prevention and treatment of nipple trauma and pain in Iran, but they have not been reviewed. This systematic review was conducted to assess herbal prevention and treatment of nipple trauma and/or pain in Iranian studies.

\section{Materials and Methods}

Based on an elementary search, there were few studies conducted on prevention and treatment of nipple pain and/or trauma in Iran. As review was done based on systematic strategy, therefore, the inclusion criteria was considered broad to get the best state of the current research on this topic. Studies were eligible if they included mothers suffering from nipple trauma and/or nipple pain. Participants of any age were included. Most included interventions used medicinal plants for this problem. These interventions included Saqez ointment, menthol essence, Aloe vera gel, Ziziphus jujuba lotion, Calendit-E cream and curcumin extract, peppermint gel, peppermint water, lanolin cream, peppermint and dexpanthenol cream.

In this systematic review, selection and data collection were based on Preferred Reporting Items for Systematic Reviews (PRISMA). All the Iranian indexed publications in English and in Persian were searched from inception to 26 December 2017 on the basis of PubMed, Proquest, Scopus, Science Direct, Medline, SID, IranMedex, Magiran, and Google Scholar. The results were reported qualitatively. For the optimal searching, general Persian and English keywords/Mesh terms such as nipples OR nipple trauma OR nipple injuries OR nipple wound OR nipple fissure OR nipple sore OR nipple pain combined with treatment OR breastfeeding OR clinical trials and all the possible combinations of these words were searched. Searches were limited to randomized clinical trials (RCTs). This review was done in several stages such as determining the title of the study, data collection, analysis and interpretation which were based on preferred reporting items for systematic reviews and meta-analyses (PRISMA). Studies identified from reference list searches were assessed for relevance to the study title. The first author performed the initial title and abstract search for articles that included interventions for treating breastfeeding women with nipple trauma and/or pain. The second author replicated the same search separately with the same results. Full-text articles were independently screened by two authors. Search results were discussed according to the including criteria by the reviewers and as there was no disagreements, a third reviewer was not consulted. Outcomes variables were extracted from the papers by one reviewer and checked by the other. Data were managed in Microsoft Excel.

\section{Results}

A total of 230704 articles were found from the electronic searches (see Figure 1 for PRISMA flow chart). A total of 70 duplicate articles were removed, leaving 230634 articles for investigation. Of these, 230616 articles were excluded for not being relevant to the study subject. The remaining 18 full text articles were reviewed to determine eligibility. One article was considered as loss due to the unavailability to its full text, one article was a systematic review, resulting in a total of 16 papers that were assessed qualitatively. Five articles were excluded for scoring lower than 3 through Jadad scale and disqualified this review. Jadad scale was used to assess the quality of the papers. It evaluates the quality of clinical trials on the basis of randomization of the participants ( 1 point if randomization is mentioned, 1 additional point if the method of randomization is appropriate), blinding (1 point if blinding is mentioned, 1 additional point if the method of blinding is appropriate) and an account of all patients (the fate of all patients in the trial is known). It ranges from the minimum point of 1 to the maximum of 5 (14). At the end of this process, 11 studies included in this review.

Most of the participants aged more than 18 years. Selected articles were divided into the treatment and prevention of nipple trauma and/or pain. There was no individual therapy. The main outcomes were the severity of nipple fissure, nipple sore, nipple cracks, nipple trauma and/ or nipple pain. Most included studies compared herbal remedies with expressed breast milk (EBM). There were 9 treatment articles (sample size $=906$ ). In five studies, Saqez, Ziziphus jujuba, curcumin, menthol and Calendit - E were the most effective treatments of nipple trauma and/or pain in comparison with EBM based on Storr scale and visual analog scale (VAS). In two studies Saqez ointment was compared with EBM and was more effective in the treatment of nipple fissures and pain (12, 15). In one study the effect of Ziziphus jujuba fruit lotion (0.5 mL) was compared with EBM (4-5 drops) on the treatment of nipple pain. The results showed that there was a significant difference between the two groups on the severity of pain 7 and 14 days after the intervention ( $P=0.02, \quad P=0.01$, respectively) (16). Another study showed that hydro-alcoholic extracts of curcumin (1 drop) and EBM (1 drop) were effective in improving nipple cracks, but curcumin was suggested for the treatment of nipple cracks due to its antimicrobial activity, low complications and short-term healing time (17). In one study, lanolin cream, peppermint cream (consisted of Carbopol, methylparaben, triethanolamine, glycerin and $0.2 \%$ of peppermint oil) and dexpanthenol cream (5\% B complex analogue) had similar therapeutic effects on traumatic nipples (18). In one study Aloe vera was more 


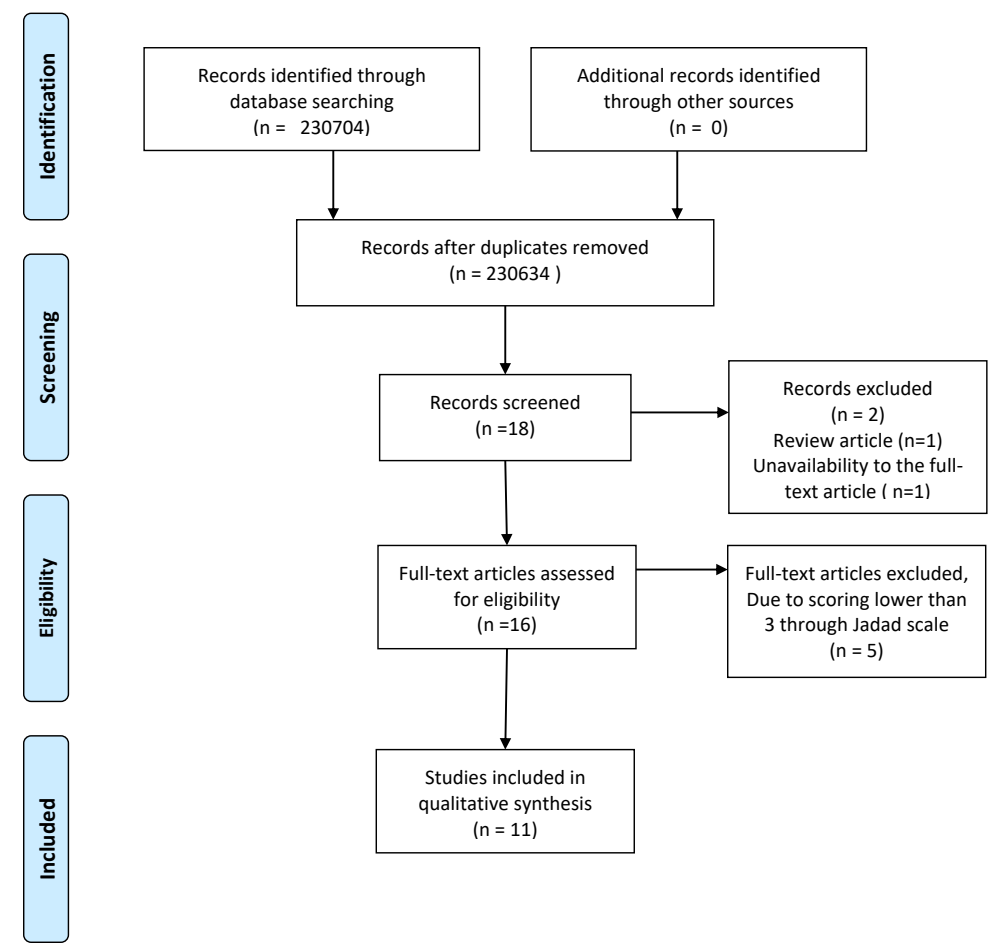

Figure 1. Flowchart of study selection.

effective than lanolin on nipple soreness healing (19). In another study menthol essence could cure nipple fissures and pain in the breastfeeding women (10). In another study, Calendit-E cream was more effective than EBM on the nipple cracks' treatment (20). In one article, Aloe vera was more effective than lanolin in nipple sore healing (21). There were only two studies on prevention of nipple trauma and/or pain (sample size $=412$ ). In one study, peppermint water was more effective than breast milk in preventing nipple cracks (22) and in another study nipple crack was less in women using peppermint compared with those who used lanolin ointment or placebo (23). The summary of the interventions and outcomes can be seen in Table 1.

\section{Discussion}

The goal of this review was to summarize and critically evaluate the literature on the prevention and treatment of nipple trauma and/or pain in Iranian studies. A total of 11 studies (sample size: 1218) were assessed. Natural remedies along with medical treatments may cure breastfeeding problems (22).

Saqez was used to improve nipple trauma and pain. Saqez contains $\alpha$-pinene and triterpenoid compounds with strong antimicrobial and antioxidant properties and thus cures wounds. The ointment of Saqez, melted with tallow, is effective in the treatment of bursting nails and chronic anal fissure (24-26). Asadi et al showed that Saqez ointment was more effective in the treatment of nipple fissures and pain than breast milk. As this study was done for the first time, investigating the conclusive efficacy of Saqez ointment on the nipple fissure, needs further similar studies. Also Saqez ointment was more effective than breast milk in healing and controlling nipple fissures during one-month follow-up (15).

On the other hand, Ziziphus jujuba fruit is one of the oldest medical species, which contains anesthetic and antiinflammatory, antioxidant and antibacterial compounds (flavonoids, cyclopeptids, alkaloids and tripens) and thus increases synthesis of collagen and accelerates wound healing $(16,27)$. Shahrahmani et al, found that Ziziphus jujuba fruit lotion could lower sore nipple pain faster than breast milk (16).

Another drug plant is turmeric (scientific name: Curcuma longa). It is a perennial member of the Zingiberaceae family and is cultivated in India and other parts of Southeast Asia. One of the main active component of this plant is curcumin. It has anti-inflammatory, analgesic, antibacterial, antifungal and antioxidant properties, thus is effective in curing wounds $(17,28)$.

Breast milk is also used for preventing and treating nipple trauma, due to having healing elements such as growth factors, anti-inflammatory and anti-microbial substances $(10,29)$. Current guidelines recommend the use of purified lanolin ointment and breast milk in the treatment of nipple fissures, based on moist wound healing principles (29). However, effectiveness of these treatments is controversial $(29,30)$. Furthermore, healing time in breast milk-treated mothers is longer compared to other treatments (31).

Lanolin improves traumatic nipples through giving 
Table 1. Samples, methods, and results of included studies

\begin{tabular}{|c|c|c|c|c|c|c|c|}
\hline $\begin{array}{l}\text { Author } \\
\text { (year) }\end{array}$ & Design & Sample & Intervention description & Comparison & $\begin{array}{l}\text { Main outcome measures and follow-up } \\
\text { duration }\end{array}$ & Outcomes & $\begin{array}{l}\text { Jadad } \\
\text { score }\end{array}$ \\
\hline $\begin{array}{l}\text { As'adi et al } \\
\text { (2017) }\end{array}$ & RCT & $\begin{array}{l}100 \text { breastfeeding women } \\
(>18 \text { years old) }\end{array}$ & $\begin{array}{l}\text { A fingertip of Saqez ointment } \\
\text { on the nipple fissure and } \\
\text { areola } 3 \text { times per day. }\end{array}$ & $\begin{array}{l}2-3 \text { drops of expressed } \\
\text { breast milk (EBM) after } \\
\text { each breastfeeding }\end{array}$ & $\begin{array}{l}\text { Nipple fissure by Storr scale, pain by VAS } \\
\text { (assessment before treatment and at days } \\
3 \text { and 7) }\end{array}$ & $\begin{array}{l}\downarrow 83 \% \text { severity of fissure } \& \downarrow 85 \% \text { severity of pain in the } \\
\text { Saqez group vs. the control group }(P<0.001) \text {. }\end{array}$ & 5 \\
\hline $\begin{array}{l}\text { As'adi et al } \\
\text { (2017) }\end{array}$ & RCT & $\begin{array}{l}100 \text { breastfeeding } \\
(>18 \text { years old) }\end{array}$ & $\begin{array}{l}\text { A fingertip of Saqez ointment } \\
\text { on the nipple fissure and } \\
\text { areola } 3 \text { times a day. }\end{array}$ & $\begin{array}{l}2-3 \text { drops of EBM after each } \\
\text { breastfeeding }\end{array}$ & $\begin{array}{l}\text { Nipple fissure by Storr scale and pain by VAS } \\
\text { (assessment during } 1 \text { month) }\end{array}$ & $\begin{array}{l}\downarrow \text { Mean of nipple fissure score }(42.62) \text { vs. the control } \\
\text { group (48.02) }(P=0.047) . \downarrow \text { Mean nipple pain intensity } \\
\text { (40.57) vs. the control group }(49.81)(P=0.056)\end{array}$ & 5 \\
\hline $\begin{array}{l}\text { Shahrahmani } \\
\text { et al (2016) }\end{array}$ & RCT & $\begin{array}{l}100 \text { primiparous women } \\
\text { with sore nipple (age } \\
\text { range: } 18-40 \text { ) }\end{array}$ & $\begin{array}{l}0.5 \mathrm{~mL} \text { of Ziziphus jujuba fruit } \\
\text { lotion, } 5 \text { times a day }\end{array}$ & $\begin{array}{l}5 \text { drops of EBM on the } \\
\text { nipples } 5 \text { times a day }\end{array}$ & $\begin{array}{l}\text { Nipple pain by pain numerical scale } \\
\text { (assessment at days } 7 \text { and } 14 \text { postpartum) }\end{array}$ & $\begin{array}{l}\text { The severity of pain on } 7^{\text {th }} \text { day } \\
\text { Treated: }(1.06 \pm 0.71) \text { EBM: }(1.48 \pm 0.88)(P=0.02) \text { and } \\
\text { 14th } \\
\text { Treated: }(0.68 \pm 0.68) \\
\text { EBM: }(1.12 \pm 0.91)(P=0.01)\end{array}$ & 4 \\
\hline $\begin{array}{l}\text { Sheinizadeh- } \\
\text { Emadi et al }\end{array}$ & RCT & $\begin{array}{l}88 \text { primiparous lactating } \\
\text { women (>18 years old) }\end{array}$ & $\begin{array}{l}1 \text { cotton soaked in } 1 \text { drop } \\
\text { of hydroalcoholic extract of } \\
\text { curcumin }\end{array}$ & $\begin{array}{l}1 \text { drop of (EBM) } 2 \text { times a } \\
\text { day after breast feeding for } \\
7 \text { days. }\end{array}$ & $\begin{array}{l}\text { Nipple crack by Storr scale } \\
\text { (assessment before treatment and at days } \\
3 \text { and 7) }\end{array}$ & $\begin{array}{l}\downarrow \text { Mean of Storr score }(0.761 \pm 0.267) \text { in comparison with } \\
\text { the EBM group }(1.23 \pm 0.426) \text { on } 3 \text { rd day }(P=0.001) \text {. A } \\
\text { significant difference between pretreatment, 3rd and } 7 \text { th } \\
\text { day of the intervention in both groups }(P<0.05) \text {. }\end{array}$ & 3 \\
\hline $\begin{array}{l}\text { Shanazi et al } \\
(2015)\end{array}$ & $\begin{array}{l}\text { Double-blind } \\
\text { RCT }\end{array}$ & $\begin{array}{l}126 \text { breastfeeding } \\
\text { mothers (age range: } 23- \\
\text { 25) }\end{array}$ & $\begin{array}{l}\text { Lanolin cream, peppermint } \\
\text { cream and the other applied } \\
\text { dexpanthenol cream }\end{array}$ & None & $\begin{array}{l}\text { Nipple pain by Store scale, nipple trauma } \\
\text { by Champion scale (assessment before } \\
\text { treatment and at days } 7 \text { and 14) }\end{array}$ & $\begin{array}{l}\text { A significant difference in comparison of } 4 \text {-time periods } \\
\text { of intervention in each group }(P<0.001) \text {. }\end{array}$ & 5 \\
\hline $\begin{array}{l}\text { Saeidi et al } \\
\text { (2015) }\end{array}$ & $\begin{array}{l}\text { Clinical blind } \\
\text { trial }\end{array}$ & $\begin{array}{l}100 \text { breastfeeding women } \\
\text { (age range } 16-40 \text { ) }\end{array}$ & $\begin{array}{l}\text { Aloe vera gel and lanolin on } \\
\text { the affected nipples } 3 \text { times a } \\
\text { day for } 7 \text { consecutive days }\end{array}$ & None & $\begin{array}{l}\text { Nipple sore by Storr scale (assessment } \\
\text { before treatment and at days } 3 \text { and } 7 \text { ) }\end{array}$ & $\begin{array}{l}\text { A significant difference between the } 2 \text { groups at } 3 \mathrm{rd} \text { and } \\
7 \text { th day }(P=0.048, P=0.003) \text {. }\end{array}$ & \\
\hline $\begin{array}{l}\text { Akbari et al } \\
(2014)\end{array}$ & RCT & $\begin{array}{l}110 \text { primiparous } \\
\text { breastfeeding women } \\
\text { (age range: } 23-26 \text { ) }\end{array}$ & $\begin{array}{l}4 \text { drops of menthol essence } \\
\text { after each feeding }\end{array}$ & $\begin{array}{l}4 \text { drops of (EBM) after each } \\
\text { feeding }\end{array}$ & $\begin{array}{l}\text { Pain by VAS, nipple fissure by Amir scale } \\
\text { (assessment at days } 10 \text { and } 14 \text { postpartum) }\end{array}$ & $\begin{array}{l}\text { A significant difference between the mean intensity of } \\
\text { pain and fissure pretreatment }(8.55 \pm 1.74) \text { and at day } 10 \\
(4.26 \pm 1.57) \text { and pretreatment and at day } 14 \text { in the case } \\
\text { group }(1.32 \pm 1.02)(P<0.001) \text {. }\end{array}$ & 3 \\
\hline
\end{tabular}


Table 1. Continued

\begin{tabular}{|c|c|c|c|c|c|c|c|}
\hline $\begin{array}{l}\text { Author } \\
\text { (year) }\end{array}$ & Design & Sample & Intervention description & Comparison & $\begin{array}{l}\text { Main outcome measures and follow-up } \\
\text { duration }\end{array}$ & Outcomes & $\begin{array}{l}\text { Jadad } \\
\text { score }\end{array}$ \\
\hline $\begin{array}{l}\text { Kazemirad et } \\
\text { al (2013) }\end{array}$ & $\begin{array}{l}\text { Single blind } \\
\text { RCT. }\end{array}$ & $\begin{array}{l}82 \text { breastfeeding women } \\
\text { (more than } 18 \text { years old) }\end{array}$ & $\begin{array}{l}\text { A fingertip of Calendit }-E \\
\text { cream } 3 \text { times a day for } 1 \\
\text { week }\end{array}$ & $\begin{array}{l}\text { 2-3 drops of (EBM) after } \\
\text { each feeding for a week }\end{array}$ & $\begin{array}{l}\text { Nipple crack by Storr scale (assessment } \\
\text { before treatment and at days } 3 \text { and } 7 \text { ) }\end{array}$ & $\begin{array}{l}\text { Reduced severity of cracks on 3rd day }(P=0.2) \text { and } 7 \text { th } \\
\text { day in the Calendit-E group }(P=0.006)\end{array}$ & 4 \\
\hline $\begin{array}{l}\text { Tafazoli et al } \\
\text { (2009), }\end{array}$ & $\begin{array}{l}\text { Single blind } \\
\text { clinical trial }\end{array}$ & 100 breastfeeding women & $\begin{array}{l}\text { Lanolin ointment and Aloe } \\
\text { vera gel } 3 \text { times a day for } 7 \\
\text { days }\end{array}$ & None & $\begin{array}{l}\text { Nipple sore by Storr (assessment before } \\
\text { treatment and at days } 3 \text { and } 7 \text { ) }\end{array}$ & $\begin{array}{l}\text { Mean nipple sore score: Aloe vera group: Pretreatment } \\
\mathrm{d}:(3.04), \\
\text { 3rd d: }(1.26), 7^{\text {th }} \mathrm{d}:(0.26) \text {. } \\
\text { Lanolin: } \\
\text { Pretreatment } \mathrm{d}:(3.1), 3 \mathrm{rd} \mathrm{d}:(1.7) \text {, } \\
7^{\text {th }} \mathrm{d}:(1.02) \text {. } \\
\text { A significant difference between } 2 \text { groups at } 3 \mathrm{rd} \text { and } 7 \text { th } \\
\text { days }(P=0.048, P=0.003) \text {. }\end{array}$ & 4 \\
\hline $\begin{array}{l}\text { Melli et al } \\
\text { (2007). }\end{array}$ & RCT & $\begin{array}{l}196 \text { primiparous } \\
\text { breastfeeding women } \\
\text { (more than } 18 \text { years old) }\end{array}$ & $\begin{array}{l}\text { Soaked cotton with } \\
\text { peppermint water after each } \\
\text { feeding for } 14 \text { days }\end{array}$ & $\begin{array}{l}\text { Soaked cotton with (EBM) } \\
\text { after each feeding }\end{array}$ & $\begin{array}{l}\text { Crack by Amir scale (expressed in } \mathrm{mm} \text { ) } \\
\text { (assessment at days } 4,8 \text { and } 14 \text { ) }\end{array}$ & $\begin{array}{l}\text { Less nipple cracks (9\%) compared with EBM }(27 \% \text {; } \\
P=0.01) \text { and in comparison with no treatment } \\
\text { (relative risk } 3.6,95 \% \mathrm{Cl}: 2.9,4.3) \text {. Nipple pain was } \\
\text { less in comparison with EBM (OR 5.6, } 95 \% \mathrm{Cl}: 2.2,14.6 \text {; } \\
P=0.005) \text {. }\end{array}$ & 3 \\
\hline $\begin{array}{l}\text { Melli et al } \\
\text { (2007). }\end{array}$ & $\begin{array}{l}\text { Double } \\
\text { blinded RCT }\end{array}$ & $\begin{array}{l}216 \text { primiparous } \\
\text { breastfeeding women } \\
\text { (age range: } 24-30 \text { ) }\end{array}$ & $\begin{array}{l}\text { Three groups, purified } \\
\text { lanolin, peppermint gel and } \\
\text { placebo gel }\end{array}$ & & $\begin{array}{l}\text { Crack by Amir scale (expressed in } \mathrm{mm} \text { ) } \\
\text { (assessment at days } 4,7,10,14 \text { and } 42 \text { ) }\end{array}$ & $\begin{array}{l}\text { Higher relative risk of nipple crack in the lanolin group } \\
\text { (RR: } 2.41,95 \% \mathrm{Cl}: 1.20-3.01) \text { compared with peppermint } \\
\text { group (RR: } 1.85,95 \% \mathrm{Cl}: 1.64-3.10) \text {. }\end{array}$ & 5 \\
\hline
\end{tabular}


moisture to the nipples (18). Lanolin is an organic ester which is obtained from sheepskin and is mixed with about $25 \%-30 \%$ of water $(32,33)$. It can be used alone or as a vehicle for herbal ointment.

Aloe vera has also been used to improve nipple trauma. It has healing, anti-inflammatory, analgesic, anti-virus, antibacterial, antifungal, antioxidant and emollient effects. Its inflammatory effect is due to having salicylic acid (inhibits synthesis of histamin) and oxidation of arachidonic acid (inhibits synthesis of prostaglandins) $(34,35)$. Tafazoli et al concluded that Aloe vera was more effective than lanolin in nipple sore healing (21). But, Shanazi et al showed that lanolin, peppermint, and dexpanthenol creams had similar therapeutic effects on traumatic nipples (18). In a study performed by Saeidi et al, Aloe vera was more effective than lanolin on nipple soreness healing (19).

Peppermint (scientific name: Mentha piperita) was used to prevent or cure nipple trauma. Peppermint has antiseptic, calming and numbing effects and has been used to relieve skin irritations and makes it resistant to cracks (36). Menthol affects the cell membrane. It attacks microorganisms and inflammatory factors and thus prevents damage to tissue cells $(37,38)$. Menthol has a pain killing activity. It affects $\kappa$-opioide receptors and thus restrains flow and transmission of pain signals and leads to less feeling of pain (39). In a study done by Singh et al. on the antioxidant and antibacterial effects of peppermint, concluded that peppermint oil had a strong antibacterial activity and this effect was comparable with those of gentamycin (40). Akbari et al (10) found that menthol essence could cure nipple fissures in the breastfeeding women. Peppermint water also was effective in the prevention of nipple pain and damage (22). In another study done by Melli et al, prophylactic peppermint gel usage was associated with fewer nipple cracks. It was more effective than lanolin and placebo (23).

Calendit-E cream is composed of Calendula officinalis and Echinacea angustifolia which improves skin inflammation and has wound healing effects. Kazemirad et al concluded that Calendit-E cream was more effective than EBM on the nipple crack's treatment (20).

It can be concluded from all the herbal medicine reviewed in this study that the presence of flavonoids and terpenoids with anti-inflammatory, antimicrobial, antifungal and antivirus properties and the materials effective on the skin collagen can accelerate nipple trauma healing $(10,21)$. Almost all mothers were given a standardized breastfeeding education with face-to-face demonstrations before starting breastfeeding. It might show that faceto-face instructions on breastfeeding techniques can be effective in prevention and improvement of nipple trauma and nipple pain. The correct positioning and good latch-on are dominant factors of reducing nipple pain and trauma. (41). However, more studies are needed to demonstrate conclusive results. Each study used a special medicinal plant in this review and thus more similar studies are needed to judge about the definitive efficacy. Furthermore, due to the subjective impression of pain in the participants, pain scoring bias may occur. Also failure to control mental issues, obligation to regular breastfeeding of the mothers, admission of the treatments by the participants and the tendency of health care personnel to a special treatment are the possible bias of the results of these studies.

It should be noted that no serious treatment related adverse effects were reported from the included studies. However, the results reported here should be interpreted with caution due to the small sample size of the articles which may lead to incorrect conclusion of the results. Furthermore, pain scoring bias may occur due to the subjective feeling of pain. Failure to control mental and environmental issues affecting mothers, admission of the prescribed treatment by the mother and the desire of health care providers to a special remedy are the other possible bias to be mentioned.

\section{Conclusion}

Peppermint is an effective herbal remedy for preventing nipple trauma and /or pain. In addition, Saqez, Ziziphus jujuba, curcumin, menthol, Aloe vera, Calendit-E were the most effective treatments of nipple trauma and /or pain. But, as each study used a special medicinal plant in this review, judgment about the definitive efficacy of these remedies needs further accurate studies.

\section{Authors' contributions}

All the authors contributed to data collection and preparation of the manuscript equally. All read the final version and confirmed for publication.

\section{Conflict of interests}

The authors declared no competing interests.

\section{Ethical considerations}

Ethical issues have been completely observed by the authors.

\section{Funding/Support}

None.

\section{References}

1. World Health Organization. Breastfeeding. Geneva, Switzerland: World Health Organization; 2017.

2. Tafazoli M, Ebrahimi A, Mohammadzadeh A, Esmaeely $\mathrm{H}$. The effct of correcting breast feeding conditon on the prevention of breast fissure. Iran J Obstet Gyneco Infert. 2015;17(138):10-7. doi: 10.22038/ijogi.2015.4197.

3. Oguz S, Isık S, Cakir Gungor AN, Seker M, Ogretmen Z. Protective efficacy of olive oil for sore nipples during nursing. J Fam Med Community Health. 2014;1(4):1-4.

4. Kent JC, Ashton E, Hardwick CM, Rowan MK, Chia 
ES, Fairclough KA, et al. Nipple pain in breastfeeding mothers: incidence, causes and treatments. Int J Environ Res Public Health. 2015;12(10):12247-63. doi: 10.3390/ ijerph 121012247.

5. Ziemer MM, Pigeon JG. Skin changes and pain in the nipple during the 1st week of lactation. J Obstet Gynecol Neonatal Nurs. 1993;22(3):247-56. doi: 10.1111/j.1552-6909.1993. tb01806.x.

6. Giugliani ER. [Common problems during lactation and their management]. J Pediatr (Rio J). 2004;80(5 Suppl):S147-54. doi: 10.1590/S0021-75572004000700006.

7. Sayed Ahmed EM, Abd El fattah Mohamed H, Abu-talib YM. Evidence based guideline using to alleviate Traumatic nipple among nursing mothers. World J Nurs Sci. 2015;1(3):35-44. doi: 10.5829/idosi.wjns.2015.1.3.93201.

8. Dias JS, Vieira TO, Vieira GO. Factors associated to nipple trauma in lactation period: a systematic review. Revista Brasileira de Saúde Materno Infantil. 2017;17(1) :27-42. doi: 10.1590/1806-93042017000100003.

9. Essa RM, Ebrahim EM. Effect of breast milk versus therapeutic honey (Apicare) on cracked nipples' healing. Life Sci J. 2013;10(1):2137-47.

10. Akbari SA, Alamolhoda SH, Baghban AA, Mirabi P. Effects of menthol essence and breast milk on the improvement of nipple fissures in breastfeeding women. J Res Med Sci. 2014;19(7):629-33.

11. Page T, Lockwood C, Guest K. Management of nipple pain and/or trauma associated with breast-feeding. JBI Reports. 2003;1(4):127-47. doi: doi:10.1046/j.1479697x.2003.00004.x.

12. As'adi N, Kariman N, Mojab F, Pourhoseingholi MA. The effect of Saqez (Pistacia atlantica) ointment on the treatment of nipple fissure and nipple pain in breastfeeding women. Electron Physician. 2017;9(8):4952-60. doi: 10.19082/4952.

13. Buck ML, Amir LH, Donath SM. Topical treatments used by breastfeeding women to treat sore and damaged nipples. Clinical Lactation. 2015;6(1):16-23. doi: 10.1891/21580782.6.1.16.

14. Jadad AR, Moore RA, Carroll D, Jenkinson C, Reynolds DJ, Gavaghan DJ, et al. Assessing the quality of reports of randomized clinical trials: is blinding necessary? Control Clin Trials. 1996;17(1):1-12. doi: 10.1016/01972456(95)00134-4.

15. As'adi N, Kariman N, Mojab F, Pourhoseingholi MA. The effect of Saqez (Pistacia atlantica) ointment on nipple fissure improvement in breastfeeding women during onemonth follow-up. Avicenna J Phytomed. 2017;7(6):477-85.

16. Shahrahmani N, Amir Ali Akbari S, Mojab F, Mirzai M, Shahrahmani H. The effect of Zizyphus Jujuba fruit lotion on improvement of nipple fissure pain in breastfeeding primipara women. Iran J Obstet Gynecol Infertil. 2016;19(35):13-21.

17. Sheinizadeh-Emadi S, Ehsani P, Dahanzadeh S, Haghighizadeh M. Comparison evaluation of Curcumin (Curcuma longa extract) with the application of expressed breast milk in the treatment of nipple cracks in lactating primiparous women: A randomized clinical trial. J Clin Nurs Midwifery. 2015;4(2):11-9.

18. Shanazi M, Farshbaf Khalili A, Kamalifard M, Asghari Jafarabadi M, Masoudin K, Esmaeli F. Comparison of the effects of lanolin, peppermint, and dexpanthenol creams on treatment of traumatic nipples in breastfeeding mothers. J Caring Sci. 2015;4(4):297-307. doi: 10.15171/jcs.2015.030.

19. Saeidi R, Tafazoli M, Gholami M, Mazloom R. New treatment for nipple soreness in breastfeeding mothers: A clinical trial study. Iranian Journal of Neonatology. 2015;6(2):48-51. doi: 10.22038/ijn.2015.4495.

20. Kazemirad M, Khodakarami N, Salamzadeh J, Nasiri N, Kazemi M, Moattar F. Comparison of Calendit -E cream versus expressed breast milk on nipple crack's treatment in breast feeding women. Adv Nurs Midwifery. 2013;23(80):19.

21. Tafazoli M, Saeedi R, Gholami Robatsangi M, Mazloom SR. Aloevera gel Vs. lanolin ointment in the treatment of nipple sore: a randomized clinical trial. Tehran Univ Med J. 2010;67(10):699-704.

22. Sayyah Melli M, Rashidi MR, Delazar A, Madarek E, Kargar Maher MH, Ghasemzadeh A, et al. Effect of peppermint water on prevention of nipple cracks in lactating primiparous women: a randomized controlled trial. Int Breastfeed J. 2007;2:7. doi: 10.1186/1746-4358-2-7.

23. Melli MS, Rashidi MR, Nokhoodchi A, Tagavi S, Farzadi $\mathrm{L}$, Sadaghat K, et al. A randomized trial of peppermint gel, lanolin ointment, and placebo gel to prevent nipple crack in primiparous breastfeeding women. Med Sci Monit. 2007;13(9):Cr406-11.

24. Bahmani M, Saki K, Asadbeygi M, Adineh A, Saberianpour $\mathrm{SH}$, Rafieian-Kopaei M, et al. The effects of nutritional and medicinal mastic herb (Pistacia atlantica). J Chem Pharm Res. 2015;7(1):646-53.

25. Bozorgi M, Memariani Z, Mobli M, Salehi Surmaghi MH, Shams-Ardekani MR, Rahimi R. Five Pistacia species (P. vera, P. atlantica, P. terebinthus, P. khinjuk, and P. lentiscus): a review of their traditional uses, phytochemistry, and pharmacology. Sci World J. 2013;2013:219815. doi: $10.1155 / 2013 / 219815$.

26. Haghdoost F, Baradaran Mahdavi MM, Zandifar A, Sanei $\mathrm{MH}$, Zolfaghari B, Javanmard SH. Pistacia atlantica Resin Has a Dose-Dependent Effect on Angiogenesis and Skin Burn Wound Healing in Rat. Evid Based Complement Alternat Med. 2013;2013:893425. doi: 10.1155/2013/893425.

27. Preeti, Tripathi S. Ziziphus jujuba: A phytopharmacological review. Int J Res Dev Pharm life Sci. 2014;3(3):959-66.

28. Jurenka JS. Anti-inflammatory properties of curcumin, a major constituent of Curcuma longa: a review of preclinical and clinical research. Altern Med Rev. 2009;14(2):141-53.

29. Marrazzu A, Sanna MG, Dessole F, Capobianco G, Piga MD, Dessole S. Evaluation of the effectiveness of a silver-impregnated medical cap for topical treatment of nipple fissure of breastfeeding mothers. Breastfeed Med. 2015;10(5):232-8. doi: 10.1089/bfm.2014.0177.

30. Cadwell K, Turner-Maffei C, Blair A, Brimdyr K, Maja McInerney Z. Pain reduction and treatment of sore nipples in nursing mothers. J Perinat Educ. 2004;13(1):29-35. doi: 10.1624/105812404x109375.

31. As'adi N, Nourossadat K, Shahrahmai H, Ghalandari S, Khodakarami N. A systematic review of clinical trials in the treatment of sore nipples and nipple pain in breastfeeding women. Iran J Obstet Gynecol Infertil. 2016;19(6):22-33. doi: $10.22038 /$ ijogi.2016.6963. 
32. Coca KP, Abrao ACFV. La evaluación del efecto de la lanolina en la cicatrización de los traumas del pezön. [An evaluation of the effect of lanolin in healing nipple injuries]. Acta Paul Enferm. 2008;21(1):11-6. doi: 10.1590/S010321002008000100002.

33. Abou-Dakn M, Fluhr JW, Gensch M, Wockel A. Positive effect of HPA lanolin versus expressed breastmilk on painful and damaged nipples during lactation. Skin Pharmacol Physiol. 2011;24(1):27-35. doi: 10.1159/000318228.

34. Eshgizade $M$, Basiri Moghaddam M, Mohammadzadeh Moghaddam H, Mahmoudian A, Mina M. Comparison of the effect of olive oil, Aloe vera extract and breast milk on healing of breast fissure in lactating mothers: A Randomized Clinical Trial. Qom Univ Med Sci J. 2016;10(3):19-27.

35. Barati AH, Fazeli F, Lotfipour M. Effect of Aloe vera on some indicators of cell damage after a period of aerobic exercise in male athletes. J HerbMed Pharmacol. 2015;4(3):85-8.

36. Schelz Z, Molnar J, Hohmann J. Antimicrobial and antiplasmid activities of essential oils. Fitoterapia.
2006;77(4):279-85. doi: 10.1016/j.fitote.2006.03.013 .

37. Guedon DJ, Pasquier BP. Analysis and distribution of flavonoid glycosides and rosmarinic acid in 40 Mentha $\mathrm{x}$ piperita Clones. J Agric Food Chem. 1994;42(3):679-84. doi: 10.1021/jf00039a015.

38. Izadi Z, Esna-Ashari M, Ahmadvand G, Davoodi P, Piri K. Chemical composition and antibacterial activity of the essence oil of peppermint (Mentha piperita L). Armaghane Danesh. 2009;14(3):45-54.

39. Nasri S. A review of the antinociceptive use of medicinal plants in Iran. Journal of Islamic and Iranian Traditional Medicine. 2012;3(3):293-310.

40. Singh R, Shushni MAM, Belkheir A. Antibacterial and antioxidant activities of Mentha piperita L. Arab J Chem. 2015;8(3):322-8. doi: 10.1016/j.arabjc.2011.01.019.

41. Duffy EP, Percival P, Kershaw E. Positive effects of an antenatal group teaching session on postnatal nipple pain, nipple trauma and breast feeding rates. Midwifery. 1997;13(4):189-96. doi: 10.1016/S0266-6138(97)80005-8. 